October 2013

Volume 128 Number 4 


\section{October 2013}

Volume 128 Number 4

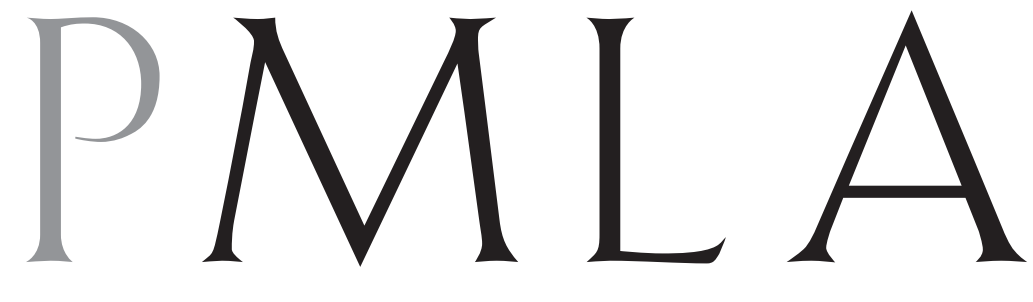

Publications of the Modern Language Association of America 
THE MODERN LANGUAGE ASSOCIATION OF AMERICA

[ Organized 1883, Incorporated 1900$]$

\section{Officers for the Term Ending 12 January 2014}

President: Marianne Hirsch Columbia University

First Vice President: Margaret W. FERGUSON

University of California, Davis

Second Vice President: Roland Greene Stanford University

Executive Director: Rosemary G. FeaL

\section{Executive Council}

FOR THE TERM ENDING 12 JANUARY 2014

JONATHAN ARAC

University of Pittsburgh

LAWRENCE I. BUELL

Harvard University

DOROTHEA HeITSCH

University of North Carolina, Chapel Hill

RICHARD M. OHMANN Wesleyan University

FOR THE TERM ENDING 11 JANUARY 2015

Barbara K. Altmann University of Oregon

Debra Ann Castillo Cornell University

María Herrera-Sobek

University of California, Santa Barbara

FOR THE TERM ENDING 10 JANUARY 2016

SAMER M. Ali

University of Texas, Austin

LANisa Kitchiner

Howard University

Lutz KoePNICK

Vanderbilt University

Mecca Jamilah Sullivan

Rutgers University, New Brunswick

FOR THE TERM ENDING 8 JANUARY 2017

Alicia M. De la Torre Falzon

Northern Virginia Community College, Annandale Campus

Donald E. Hall

Lehigh University

Paula M. Krebs

Bridgewater State University

\section{Trustees of Invested Funds}

Herbert Lindenberger San Francisco, California

Malcolm B. Smith (Managing Trustee) New York, New York

Catharine R. Stimpson New York, New York
PMLA (ISSN 0030-8129) is published five times a year, in January, March, May, October, and November, by the Modern Language Association of America. Membership in the association is open to persons who are professionally interested in the modern languages and literatures. Annual (calendar-year) dues, which include subscription to $P M L A$, are $\$ 22$ for graduate student members (up to a maximum of seven years) and are based on income for regular members: income under $\$ 15,000, \$ 27$; income $\$ 15,000$ $\$ 20,000, \$ 44$; income $\$ 20,000-\$ 30,000, \$ 54$; income $\$ 30,000-\$ 40,000, \$ 76$; income $\$ 40,000-\$ 50,000$ $\$ 91$; income $\$ 50,000-\$ 60,000, \$ 108$; income $\$ 60,000-\$ 70,000, \$ 125$; income $\$ 70,000-\$ 80,000, \$ 140$ income $\$ 80,000-\$ 100,000, \$ 157$; income $\$ 100,000-\$ 120,000$, $\$ 179$; income $\$ 120,000-\$ 140,000, \$ 201$; in come $\$ 140,000-\$ 160,000, \$ 223$; income $\$ 160,000-\$ 180,000$, $\$ 250$; income $\$ 180,000-\$ 200,000$, $\$ 277$; in come over $\$ 200,000, \$ 304$. Joint membership, which provides one copy of the January, March, May, and October issues of PMLA but two copies of all other publications, is available to two individuals sharing the same household. The dues for a joint membership are $\$ 44$ above the dues that would be paid by the higher-income member alone. Foreign members pay the same as regular members (use the Americandollar equivalent to ascertain the dues category). Membership applications are available on request and at the MLA Web site (www.mla.org).

For libraries and other institutions, a subscription in 2014 to the electronic format of PMLA alone is $\$ 190$ and to the print and electronic formats is $\$ 210$ (domestic and Canadian) or $\$ 240$ (foreign). Sub scriptions also include online access to the 2002-13 volumes. For an additional \$180, institutional subscribers receive a clothbound edition of the 2014 volume of $P M L A$. Agents deduct four percent as their fee. Claims for undelivered issues will be honored if they are received within six months of the publication date; thereafter the single-issue price will be charged. To order an institutional subscription, call or write the Member and Customer Services Office of the association (646 576-5166; subscrip@mla.org).

Single copies of the January, March, May, and October issues can be purchased for $\$ 12$ each; the November (Program) issue is $\$ 35$. Issues for the current year and the previous one are available at the MLA Bookstore (www.mla.org/store/CID70) and from the Member and Customer Services Office of the association (646 576-5161; bookorders@mla.org).

An online archive of PMLA issues from 1884 to 2007 is available through JSTOR (www.jstor.org).

Volumes up to 2000 can be obtained on microfilm from NA Publishing, Inc., PO Box 998, Ann Arbor, MI 48106-0998 (800 420-6272; info@napubco.com; www.napubco.com/umi.html).

The office of publication and editorial offices are located at 26 Broadway, 3rd floor, New York, NY 10004-1789 (646 576-5000; pmlasubmissions@mla.org).

All communications concerning membership, including change-of-address notifications, should be sent to the Member and Customer Services Office, MLA, 26 Broadway, 3rd floor, New York, NY 10004 1789 (646 576-5151; membership@mla.org). If a change of address also involves a change of institutional affiliation or a new e-mail address, that office should be informed of this fact at the same time.

Periodicals postage paid at New York, NY, and at additional mailing offices.

(c) 2013 by The Modern Language Association of America. All rights reserved. Printed in the United States of America.

MLA and the MODERN LANGUAGE ASSOCIATION are trademarks owned by the Modern Language Association of America.

Library of Congress Catalog Card Number 12-32040. United States Postal Service Number 449-660. POSTMASTER: Send address changes to PMLA, Member and Customer Services Office, MLA 26 Broadway, 3rd floor, New York, NY 10004-1789. 


\section{Contents}

\section{OCTOBER 2013}

861 A Statement of Editorial Policy

862 Forthcoming in PMLA

862 Features in PMLA

865 Editor's Column-From Penn Station to Trenton: The Language Train

872 Sonorous Duration: Tristram Shandy and the Temporality of Novels

Amit YaHAV

888 Prolepsis and the Tradition of Juvenile Writing: Henry Kirke White and Robert Southey

LAURIE LANGBAUER

907 The Plagiarist's Craft: Fugitivity and Theatricality in Running a Thousand Miles for Freedom

GeOFFrey SANBORN

923 Strolling through the Slums of the Past: Ralph Werther's Love Affair with Victorian Womanhood in Autobiography of an Androgyne

AARon SHAHEEN

\section{theories and methodologies}

\section{Early American Literature}

938 Mistranslation, Unsettlement, La Navidad

ANNA BRICKHOUSE

947 Soul Matters

JOANNA BROOKS

953 Early America and the Revolutionary Pacific

Michelle Burnham

961 What's in a Date? Temporalities of Early American Literature Sandra M. Gustafson

968 Cosmic American Studies JARED HickMAN

976 Mapping the Hemispheric Divide: The Colonial Americas in a Collaborative Context

Stephanie Kirk
PUBLICATIONS OF THE MODERN LANGUAGE ASSOCIATION OF AMERICA

[ Published five times a year $]$

Volumes ONLINE

VOLS. 1-122 (1884-2007), JSTOR

VoLs. 117-28 (2002-13), MLAJournals.org

ONLINE INDEX

Vols. 1-128 (1884-2013)

MLA International Bibliography

Print Indexes

VoLS. 1-50, 1935; 51-60, 1945; 51-79, 1964

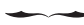

Editor

Simon GIKANDI

Princeton University

Managing Editor

JUDY GOULDING

Associate Managing Editor ERIC WIRTH

Associate Editor

BARNEY LATIMER

Assistant Editors

Christiane Angeli

JOHN D. GolbaCH

Advertising Manager and Submissions Associate

ANNABEL SCHNEIDER

Administrative Assistant

Claire Luchette

\section{Editorial Board}

Evelyne Ender, 2014 Hunter College, City University of New York Julia Hell, 2015

University of Michigan, Ann Arbor

CHRIsTOPHER LOOBY, 2014

University of California, Los Angeles

DeIDRe Shauna LynCH, 2014

University of Toronto

Kalpana Seshadri, 2015 Boston College

NoËL VALIS, 2015 Yale University

Advisory Committee

SUSAN Z. ANDRADE, 2014

University of Pittsburgh

Arturo Arias, 2014

University of Texas, Austin

Eva BADOWsKa, 2016

Fordham University

EMILIE L. BERGMANN, 2014

University of California, Berkeley

PATRICIA LynN Bizzell, 2014

College of the Holy Cross

Marcellus Blount, 2015 Columbia University

Susan Berry Brill de Ramírez, 2016 Bradley University

Martin Joseph Camargo, 2015

University of Illinois, Urbana

JULIE ANN CARLSON, 2015

University of California, Santa Barbara

ROBERT J. CORBER, 2016 Trinity College (continued) 
Advisory Committee (continued) JENNY Davidson, 2015 Columbia University

Patrick Michael Erben, 2016 University of West Georgia

STEPhen M. Fallon, 2015

University of Notre Dame

GRANT FARRED, 2015 Cornell University

Carla A. Freccero, 2014

University of California, Santa Cruz

Debiani Ganguly, 2015

Australian National University

Rebecca Garden, 2015, Upstate Medical

University, State University of New York Susan Gillman, 2016

University of California, Santa Cruz

LAUREN M. E. GoOdLAD, 2014

University of Illinois, Urbana

Maryemma Graham, 2014 University of Kansas

JaCK HaLberstaM, 2015

University of Southern California

Shirley Brice Heath, 2014 Stanford University

Donald Hedrick, 2015

Kansas State University

Rosanne M. Kennedy, 2014

Australian National University

MatThew J. KinserviK, 2016

University of Delaware, Newark

Christopher M. LuPKe, 2015

Washington State University, Pullman

JANN MATLOCK, 2016

University College London

LeErom Medovol, 2014

Portland State University

BRINDA J. MeHTA, 2015 Mills College

Anuradha Dingwaney Needham, 2014 Oberlin College

Graziella Parati, 2016 Dartmouth College

ANDrew C. PARKer, 2016

Rutgers University, New Brunswick

Marta C. Peixoto, 2014 New York University

Gema Pilar Pérez-Sánchez, 2014 University of Miami

Charles A. Perrone, 2016 University of Florida

Kevin M. F. Platt, 2016

University of Pennsylvania

KaRLIS RACEVSKIS, 2015

Ohio State University, Columbus

Ann Marie Rasmussen, 2016 Duke University

JosÉ M. RodRíGUEZ GARCÍA, 2015 Duke University

GABRIELE M. SchWAB, 2015

University of California, Irvine

DAVID R. SHUMWAY, 2016

Carnegie Mellon University

Miнoкo SuzUKi, 2014 University of Miami

Johannes VON MOLTKe, 2016

University of Michigan, Ann Arbor

RichaRd H. WATTS, 2014

University of Washington, Seattle

DAVID JOSEPH WRISLEY, 2015

American University of Beirut
OCTOBER 2013

983 Early American Literature and Its Exclusions

Lloyd Pratt

989 Early American Religion in a Postsecular Age

Sarah RivetT

997 Early American Studies-by the Book

Phillip H. Round

1004 Forum

Paul Ardoin, John Champagne, Eric Gardner, and

Barbara Hochman

1009 Minutes of the MLA Executive Council

1018 In Memoriam

1020 Index of Advertisers

1043 Abstracts

1045 Contents of Volume 128 (2013) 